\title{
Basic Principles for Chinese Sustainable Higher Education
}

\author{
Changqing Pang \\ Shandong University of Science and Technology(Jinan \\ Campus) \\ Dept. of Basic Courses \\ Jinan, China \\ E-mail: 13853184438@163.com
}

\author{
Di Pang \\ Dept. of Social Sciences \\ University of Tsukuba \\ Tsukuba, Japan \\ E-mail: houteki1997@yahoo.co.jp
}

\author{
Huimin $\mathrm{Xu}$ \\ Shandong University of Science and Technology \\ Dept. of Foreign Languages \\ Qingdao, China \\ E-mail: 15764255564@163.com
}

\begin{abstract}
Chinese higher education is undoubtedly transferring and developing from compulsory education or exam-oriented education to competence education, but anyhow, this process is very slow and also misconcepted, the primary reason for which is that Chinese universities are still practicing ESD(Education for Sustainable Development)for higher education not efficiently. This paper analyzes some prevalent shortsighted practices such as bureaucratic regulations, isolations and academic barriers, etc. Correspondingly, the paper gives to much emphasis on such basic principles for Chinese sustainable higher education as establishing academic-centered regulation systems, valuing-teaching idea, academic integration, competence education, preferential treatment to teachers, and openness to the world, local communities and societies etc.
\end{abstract}

Keywords-principle; ESD; Chinese higher education; sustainable

\section{INTRODUCTION}

The concept of ESD[1] (Education for Sustainable Development,ESD)was first put forward by UNESCO as early as the year of 1988. Later in the year of 1990, Talloires Declaration was signed by 280 universities from 40 countries at the conference of ULSF(University Leaders for a Sustainable Future[2], committing to the future course of world sustainable higher education. More importantly, UNESCO decided to name the period from the year of 2005 to 2014 as "UN Decade of Education for Sustainable Development 20052014"[3], encouraging worldwide sustainable education including higher education. All these efforts have pushed ESD forward from vague concepts to concrete activities. However, declarations are just declarations, and only little achievement was made, since most universities soon forgot their promises and went back to old tracks. Worse than that, in addition to the slow progress by university authorities, university students also lack of qualities toward human problems, environmental problems, and social problems, etc. It is crucial to make thorough change to university regulations, teaching methodologies and students orientations etc. in order to ESD develop faster than ever. In terms of Chinese universities, it is more urgent to satisfy the needs for high education of the public as well as committing to world higher education aspect.

\section{ACADEMIC-CENTERED REGULATION SYSTEM VS. BUREAUCRATIC REGULATION SYSTEM}

In China, due to the deep-rooted traditions, higher education is regulated in the same way as business or government does, which is called "Bureaucratic Regulation System". As is known to all, such a system greatly harms the healthy development of academic freedom and vitality, hindering Chinese universities from developing sustainably.

In spite of stressing the major problem over and over, higher education is still like a business or a small government where teachers have to subject themselves to school authorities and students subject themselves to school authorities too. So, the ridiculous thing is that it is the school authorities who decide everything about university affairs, who order teachers to do this and that, and order students to obey every rule. In this way, teachers lose their motivation to explore their free will and mind, and they are left just explaining textbooks to students, which is exactly like workshop manufacturing same products. In the long run, talents will be buried and creation ability will be killed. Higher education is nothing but a machine.

To completely get rid of such bureaucratic higher education regulation systems, academic-centered system have to be established, which requires the central government to explicitly say no to the nasty system. In fact, barriers exist due to the long history of the old system, but if not, Chinese higher education will be still left behind. The mission of higher education will never be achieved. In this case, new laws or regulations by the central government have to be made in order to reform the system in the top-to-bottom way, where professors have the 
sole rights to decide what to teach and what to research. Until then, higher education is facing dead end.

\section{VALUING TEACHING VS. OVERSTRESSING RESEARCH}

Almost in all Chinese universities, scientific research enjoys greater advantages and higher status that teaching work. No matter how well you do teaching job but without any SCI journal papers, the title of professor will never fall on you. In this case, no matter they are capable or not, all teachers stick their heads into paper publishing, leaving teaching work dull and fruitless. On the other hand, overstressing papers gives rise to dishonest cheatings in writing them, which constitutes very dangerous academic corruption. Consequently, both scientific research and teaching work begin to slide down. Obviously, higher education has become a kind of tool to earn fame and money. How can we expect such education to become sustainable?

It is well known that research and teaching are indispensible. Many research fruits are discovered or invented in the course of teaching. Ignoring teaching equals to sacrificing the substance for the shadow. In this sense, highly valuing teaching work has to be given top priority in universities instead of degrading it to motivate teachers and students to explore academic world in a free environment.

\section{ACADEMIC INTEGRATION VS. SPECIALIZATION}

Education for sustainable development is a completely new direction, requiring cooperation and understanding between different disciplines in order to adjust to the highly integrated social and world problems.

Unfortunately, academic barriers between disciplines are prevalent in Chinese universities. Academic majors are highly divided, leaving less and less communication and connection between their learners and researchers, which makes it very difficult to deal with sophisticated practical social and scientific problems. This is largely due to the narrow academic minds and pragmatic interests.

Sustainability means coordination where different knowledge and personnel are very necessary in solving tough problems. Sustainability means thinking integration and discipline integration, much more than few interdisciplinary courses. In this case, university curriculums have to be greatly reformed to stress integration between different disciplines no matter they are humanities, sciences, or engineering.

In addition to integration of curriculum reforms, open-tothe-world principle, mind and measures also have to be built, since sustainability also means integration of academic resources home and abroad. Apparently, Chinese universities are relatively not open enough to overseas students and higher education institutions, greatly affecting education vitality and preventing them from developing internationally.

\section{COMPETENCE EdUCATION VS. COMPULSORY EDUCATION}

Sustainable education also means freethinking and creative mind. Unfortunately, compulsory education has been dominant in Chinese education for so long time that it is very hard to make a complete diversion from it. Higher education is not excluded. Anyway, compulsory education has to be abandoned since it kills free mind and creativity. Minor tinkering improvements are far from enough. Higher education has to take the lead in overturning the education mood.

Since the ultimate target for higher education is to nurse students in the aspects of character-building, decision-making, culture-understanding etc., all of which could never be built by tests or examinations. In this way, government laws or regulations have to be amended to give priority to competence education that embraces different abilities such as open mind, independent thinking, healthy characters, cultural comprehension, creative ideas etc.

Anyway, it is the college graduates who will take the main task in building the society and the world. Sustainability of the future society depends on them and their competence in taking the responsibility depends on today's education. So, higher education curriculum, test methods and teaching methods etc. have to be amended as soon as possible.

\section{PREFERENTIAL TREATMENT VS. DisCRiminAtion}

College teachers take the task of nursing sustainable college students. So, teachers` qualities, academic achievements and personalities all influence the process. In this way, it is crucial to make sure that teachers themselves are motivated to cultivate these treats. And how to? The answer is to treat them fairly and preferentially in terms of material things and respect.

However, according to the book Paying the Professoriate, A Comparison of Academic Remuneration and Contracts in 28 Countries which examines relative pay among public university teachers around the world, written by professor Philip G. Altbach from International Higher Education Study Center in Chicago University, based on buying power, university teachers in Canada are the richest, while their counterparts in China are the second poorest from the bottom. Specifically, newly employed Chinese college teachers get the lowest incomes among the world, whose average monthly income is 259 US dollars, while Canadian teachers earn 22 times more than Chinese teachers do [4]. The average monthly income for a Chinese college teacher is 720 US dollars, ranking the second from the bottom. While average monthly income for a Canadian college teacher is 10 times more than a Chinese college teacher [5]. College teachers in South Africa and India both rank among top 5 [6], which is great humiliation for Chinese college teacher, since the two countries are developing countries too and China`s economy develops much faster than the two countries. But the truth is that Chinese college teachers earn much less their brothers do. Fig.1 expresses the sharp contrast.

More than that, in addition to buying power, another criteria has to be considered, which is the percentage of teachers income to their countries' average GDP per person. Just take Ethiopia as an example. Although its university professors 
average monthly income is only 1,207 US dollars, ranking the fourth place from the bottom, comparing with the country's GDP per person, a professor's income in this country reaches 23 times more than the average income, while professors in the U.S.A., Germany, and Australia just earn 2 times more than their average GDP per person [7]. This clearly demonstrates that in Ethiopia university professors are greatly respected.

The book also points out that the brain drain or the outflow of talent is a serous problem in countries where university teachers are just given much low treatment, which greatly degrades the higher education quality, seriously endangering sustainability of higher education.

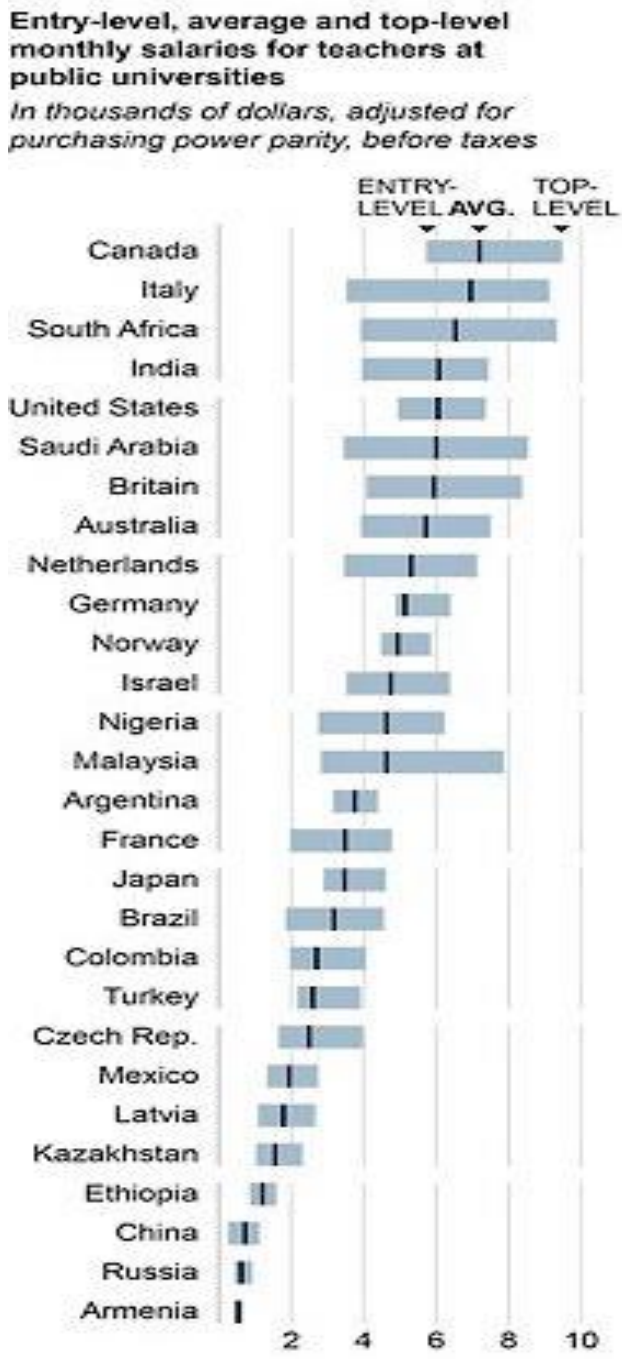

Fig. 1 Monthly Salary levels of University Teachers around the World [8]

Wealth gap matters a lot in terms of respect and dignity. You could not expect a man to take greater responsibility while just giving him a little to support his life and family. This is disrespect, humiliation, or a kind of discrimination.

It is strongly advised that fair treatment or preferable treatment has to be given to college teachers for the sake of their devotion and responsibility, for the sake of future generations, and for the sake of higher education sustainability. It is not that our economy could not afford that, but that our government does not take higher education important in fostering the future and the people. While so many countries devote too much into higher education, Chinese government lacks far behind. It is true that education sustainability will never be reached until fair respect and treatment are realized.

\section{OPENESS VS. CLOSENESS}

Sustainability also means openness, including opening to the world, opening to the societies, opening to the communities We are facing a harsh reality that all these openings are seldom realized in Chinese universities, while closeness and isolation from the outside world is very common.

Worldwide higher education internationalization has been developing steadily since the Middle Ages when universities were called "the flowers of wisdom" and students would received their education in different universities in different countries [9]. Later, Universität zu Berlin started the history of modern universities, which was characterized with higher education internationalization and academic freedom, attracting many overseas students to study there and greatly benefiting American higher education [10]. After World War II, western universities focused more on serving the societies local and worldwide, which was represented by "International Understanding and Communication" of Washington University, "Serve the World" of University of Missouri, "World Campus" of the Pennsylvania State University, and "the World Citizen" of Boston University. The Openness or the Internationalization of American universities helps American high education rank the first place worldwide [11].

While in Europe, ministers of education from 29 countries jointly sighed Bologna Declaration demanding European universities to establish joint courses and degrees to promote worldwide students to take graduate studies [12].

In addition, Australia, India, Russia, and Africa are all adopting measures to fasten their internationalization steps to promote academic research nationally and internationally.

It is not deniable that Chinese universities are beginning to catch up with western countries in the aspect of openness and internationalization, but pacing slowly. Absolutely, the transition from closeness to openness requires efforts at different levels and in different aspects. In the first place, education authorities have to take specific measures to advocate higher education institutions to take steps, while giving them freedom to do so. Secondly, it is important for universities to build strong connections with the local communities, since the major function of higher education is to serve the society and the people, which will definitely benefit both sides. Meanwhile, openness helps to build higher reputation for higher education, which in turn leads to a kind of healthy atmosphere where higher education is overwhelmingly respected and valued.

\section{SUMMARY}

In summary, I put forward the above basic principles to guide through the sustainable development for Chinese higher education, i.e. academic-centered regulation system, valuing 
teaching, academic integration, competence education, preferential treatment, and openness. While China has been greatly boosting her economy, She is feeling very hard to achieve some key breakthroughs in some high-tech areas. This is mainly due to the relatively weaker competence of scientific researches of Chinese universities, which is why we advocate sustainable development for higher education by reforming it based on the preferable principles.

\section{REFERENCES}

[1] "Education for Sustainable Development" http://en.unesco.org/themes/education-sustainable-development

[2] "The Talloires Declaration" 1990 http://ulsf.org/wp-content/uploads/2015/06/TD.pdf

[3] "UN Decade of Education for Sustainable Development 2005 - 2014" http://unesdoc.unesco.org/images/0014/001416/141629e.pdf

[4-8] Philip G. Altbach, "Paying the Professoriate: A Global Comparison of Compensation and Contracts" Routledge, 2012

[9-11] Fei Xu, "Highly Internatinalized Higher Education," http://news.swjtu.edu.cn/ShowNews-13624-0-1.shtml, 2016/11/30

[12] Joint Declaration of the European Ministers of Education convened in Bologna on 19 June 1999. 